\title{
The Culinary Poblana; Tourism Competitiveness Strategy for the city of Puebla
}

\section{La Culinaria Poblana; Estrategia de Competitividad Turística para la ciudad de Puebla}

PEREA-BALBUENA, José Ángel †**, CARRASCO-ROMERO, Víctor Josaphat, LÓPEZ-PALACIOS, María de Lourdes and MALDONADO-RESENDIZ, Jorge Ángel

Benemérita Universidad Autónoma de Puebla, Facultad de Administración. 4 Sur \#104; Col. Centro C.P. 72000; Puebla de Zaragoza, Puebla, México

ID $1^{\text {st }}$ Author: José Ángel, Perea-Balbuena / ORC ID: 0000-0002-1868-4450, CVU CONACYT ID: 913019

ID $1^{\text {st }}$ Coauthor: Víctor Josaphat, Carrasco-Romero / ORC ID: 0000-0001-6395-3608, CVU CONACYT ID: 450396

ID $2^{\text {nd }}$ Coauthor: María de Lourdes, López-Palacios / ORC ID: 0000-0002-8397-8981, CVU CONACYT ID: 416695

ID $3^{\text {rd }}$ Coauthor: Jorge Ángel, Maldonado-Reséndiz / ORC ID: 0000-0003-1787-3660, CVU CONACYT ID: 1087863

\begin{abstract}
Every city, town, or local community has its land, its water, its air, its landscapes, and its buildings. For many generations, community residents have used these resources for their survival. Tourism has been an activity that has made use of these resources, in order to make them attractive and offer them in the tourist markets. The city of Puebla is located in the regional and national context for the variety of its cuisine, as this is a fusion inspired by ingredients from Mesoamerica, Europeans brought in by the Spanish conquest which in turn are inspired by the Arabian cuisine, also Asian culinary elements were integrated, which led to an extraordinary and varied regional cuisine from the eighteenth century. Currently, gastronomic tourism is presented as an important motivator of the tourist trip, so the poblana cuisine represents a competitive tool for this segment of the tourism market.
\end{abstract}

Gastronomy, Competitiveness, Promotion

\begin{abstract}
Resumen
Cada ciudad, pueblo, o comunidad local, tiene sus tierras, sus aguas, su aire, sus paisajes y sus edificaciones. Durante muchas generaciones, los residentes de las comunidades han usado estos recursos para su sobrevivencia. El turismo ha sido una actividad que ha hecho uso de dichos recursos, a fin de convertirlos en atractivos y ofertarlos en los mercados turísticos. La ciudad de Puebla es ubicada en el contexto regional y nacional por la variedad de su culinaria, ya que esta es una fusión inspirada en ingredientes de Mesoamérica, europeos traídos en la conquista española que a su vez se encuentran inspirados en la gastronomía árabe, así mismo también se integraron elementos culinarios asiáticos, lo que gestó a partir del siglo XVIII una cocina regional extraordinaria y variada. Actualmente el turismo gastronómico se presenta como un importante motivador del viaje turístico, por lo que la culinaria poblana representa una herramienta de competitividad para este segmento de mercado turístico.
\end{abstract}

Gastronomía, Competitividad, Promoción

Citation: PEREA-BALBUENA, José Ángel, CARRASCO-ROMERO, Víctor Josaphat, LÓPEZ-PALACIOS, María de Lourdes and MALDONADO-RESENDIZ, Jorge Ángel. The Culinary Poblana; Tourism Competitiveness Strategy for the city of Puebla. Journal of Administration and Finance. 2020, 7-20: 1-9

\footnotetext{
* Correspondence to Author (e-mail: perea_angel@ @otmail.com)

$\uparrow$ Researcher contributing first author.
} 


\section{Introduction}

The city of Puebla and especially its old town, is the result of various eras and countless physical and social transformations, due to different historical processes. Its heritage appreciation has been the result of different actions that have allowed to know and reflect its material and immaterial testimonies that have given it a character of historical city that allowed the inscription of World Heritage City from 1987.

Although the city of Puebla by its own characteristics of historical conformation is defined by a sixteenth century structure based on the reticular trace of viceregal origin arising from the Renaissance utopias and conceived as a city for Spaniards and for the consolidation of utopian ideals in the new world, this is added to territories of old neighborhoods, as subsequent extensions and housing establishments in colonies and subdivisions, which over time have acquired a sense of identity and certain potential heritage, both socially and in production systems. (Sánchez Hernández, 2008)

Throughout the history of humanity, it has been considered true that eating is a biological act and cooking a cultural act; culture is an accumulated wealth that has allowed societies to develop in all its dimensions, both material and spiritual. Culture is formed by diverse manifestations, such as music, painting, architecture and gastronomy. The food and the nutrition are essential properties of the life; the man is the only animal that cooks, because it transforms the instinctive activity in a mental exercise; already Faustino Cordón pointed out it, we are "culinary animals" before "social animals" making reference to the philosopher Aristotle.

The set of materials implemented for the realization of any dish, give the regions a feature of identity and authenticity, and in turn, have changed all civilizations over time. The feeding of a huge sense of belonging to a social group. (Perea, 2002)

The Mexican popular cuisine and the traditional features that make it up, are part of a complex cultural system integrated with cosmogonic concepts with symbolic values and an omnipresent ceremonial and ritual character throughout the life of the individual and the community.
Similarly, throughout history, ingredients and practices from all over the world have been incorporated into Mexican cuisine. Also, in the reflection on the food system, ideas have been introduced that are so novel and so ancient that now, in the paroxysm of globalization, we are fully aware of the essential dialectic relationship that must exist between the local and the global.

Currently, a large percentage of tourism moves in search of gastronomic delights, good food that does not lose sight of its cultural context and the reference of its roots, is a determining factor in the creation of wealth of a nation.

Within a model of responsible management of tourism, we find 4 key objectives that can give us the guideline for the creation of tourism projects: the first is the improvement of efficiency and competitiveness, the second we have to create environments of good governance and shared responsibility, in a number three expand the supply of innovative tourism products and the consolidation of routes and destinations, and finally, promote balanced tourism development from the municipal level.

In this way, the cuisine of Puebla is an important element and tool to develop quality tourism products and competitive cuisine, which allow to be a trigger to implement new tourist actions for the city of Puebla.

\section{Justification}

The design of a business model requires knowledge of the environment in which the company will operate, the industry or sector, the market and the customer segments it seeks to serve. These factors provide the context in which the organization will develop and allow us to understand the challenges that will be faced and the best way to respond to them.

One of the key factors for the definition of the strategy and the business model is the knowledge of the markets and customers. These are grouped into segments, which allows to clearly define which groups of customers will be served and their specific needs. 
Every company that participates in a service sector without realizing it has a competitive strategy, which can be found explicitly or implicitly developed, some of them well-structured through the implementation of a defined strategic planning, others due to the added value offered by internal customers to ensure the proper functioning of this, generating profitability, market positioning, process and product innovation, among others. In this way the competition determines the success or failure for any company, the competitive strategy guarantees an advantageous position from the rest of the companies in the same sector that compete for the same market, its purpose is to establish a profitable and sustainable position in front of the competition.

The essence of a good competitive strategy is to relate a company with its environment, differentiating it from the rest of those who are looking for the same customer, this advantage is in quality, price, presentation, efficiency in delivery times, product differentiation, among others.

The problems of a certain sector affect all the others; the key to success is found in the skills that each one of them has to face the problem. In Mexico the backbone of our economy is found in the Micro, Small and Medium Enterprises. According to data from Forbes, there are about 4.2 million MSMEs, which contribute about $52 \%$ of the Gross Domestic Product (GDP) and generate $70 \%$ of formal employment. Supporting these markets is of great importance for the country's development, and today they are experiencing moments of transition in which technology will become their best ally.

As a consequence of the global situation, we are going through, many businesses have been forced to be more flexible in their operation, remote collaboration solutions are now a necessity rather than an option, and many companies have realized the benefits it has brought them. Others have had to change their business, and businesses dedicated to offering products and services online have increased their sales; a sector which is expected to grow by $60 \%$ by the end of 2020. A company has a competitive advantage when it is in a better position to defend itself against competitive forces and keep customers.
There are many sources of competitive advantage: making a product with the highest quality, providing superior service to customers, achieving lower costs in rivals, having a better geographical location, designing a product that performs better than competing brands. The competitive advantage is obtained when you do something different within the traditional process of your industry and that gives you an exponential advantage over any of your competitors. Even if it is a small change, year after year you gain a little advantage, over time the company will grow until your competitors can't reach you.

To be really effective, a competitive advantage must be: difficult to match, unique, possible to maintain, clearly superior to the competition and applicable to various situations; find the advantage or competitive advantages, is a task that the same company has to go "discovering", because the existence of markets today so changing, with frequent innovations, makes companies must work every day in creating these competitive advantages, in maintaining them, in exploiting them, and go looking more emphasis on those characteristics that make us different from the rest of the competition. (Carrasco Romero, 2015)

But above all, companies must concentrate on fighting for these characteristics to be perceived and valued by our current and potential market, spreading them to place them as long as possible in the minds of clients or consumers. Finding that competitive advantage can help to achieve the success of the SME.

\section{Theoretical framework}

The choice of food is linked to the satisfaction of the body's needs, but also, to a great extent, to those of society. In this sense Kaplan and Carrasco indicate that:

"Food belongs, on the one hand, to a private and daily sphere of all human beings and, on the other hand, translates unmistakable features in which it also refers to the social position of groups in relation to the social structure of which they are part. Food culture deserves to be studied for these reasons: because it can tell us about the type and conditions of insertion of a group in the wider society" (Kaplan \& Carrasco, 1999). 
Eating behaviours are internalized by individuals as integral elements of a given sociocultural system. They allow the construction, recreation and vindication of the group's identity. As Millán points out, "in the field of food, identity is manifested by a selection of foods and by the choice of identity symbols among them". (Millán, 1991).

Eating behaviours are contemplated and valued socio-culturally within the framework of the societies that produce them; and they are, likewise, a useful and explicit instrument that people have to recreate their identity.

Eating is situated as an instrument within the field of collective identity and becomes, in this way, one of the symbolic frontiers to be taken into account among groups in contact, becoming evidence of the differential participation of individuals in a wider sociocultural framework. As Igor de Garine expresses; "it is not by chance that cooking figures in the foreground in the panoply of regional claims" (Medina, 2002)

Puebla, inherited from the colony the commercial routes, becoming a strategic point of contact among travellers coming from Europe through Cuba and entering the new Spain through Veracruz, also those coming from the Philippines through Acapulco, in this way the city, was constituted as the second in importance and was one of the least problems of food supply. The central highlands, with its dense and complex population was since colonial times the heart of Mexico and remained so throughout the nineteenth century. Its great variety of climates and its enviable geographical position allowed its inhabitants to plan a varied diet, based on corn, beans, chili and pumpkin that were produced throughout this area, likewise these pre-Hispanic ingredients were enriched with European food elements such as wheat, olive oil, pork, and various fruits and vegetables, in the same way also endorsed Asian elements such as rice, spices, coconut, mango, among others from the Philippines. Thus, the good geographical and economic position of Puebla allowed him to enjoy a very varied cuisine.

\section{The restaurant industry in Mexico}

The National Institute of Statistics and Geography's (INEGI) Statistical and Geographic Yearbook by State $(2018 ; 2019)$ records the behaviour of the Economic Units (EU); for 2017, 65,579 EU were recorded, distributed as follows: Restaurants with 43,332, cafeterias, fountains, refrigerators, soft drinks and similar establishments with 8,217, bars, canteens and similar establishments with 7,026 EU. In 2018, 54,721 EU restaurants were identified, with 39,020 , followed by cafeterias, drinking fountains, cold stores and similar establishments with 6,080 and similar, and bars, canteens and similar establishments with 450 and similar, respectively.

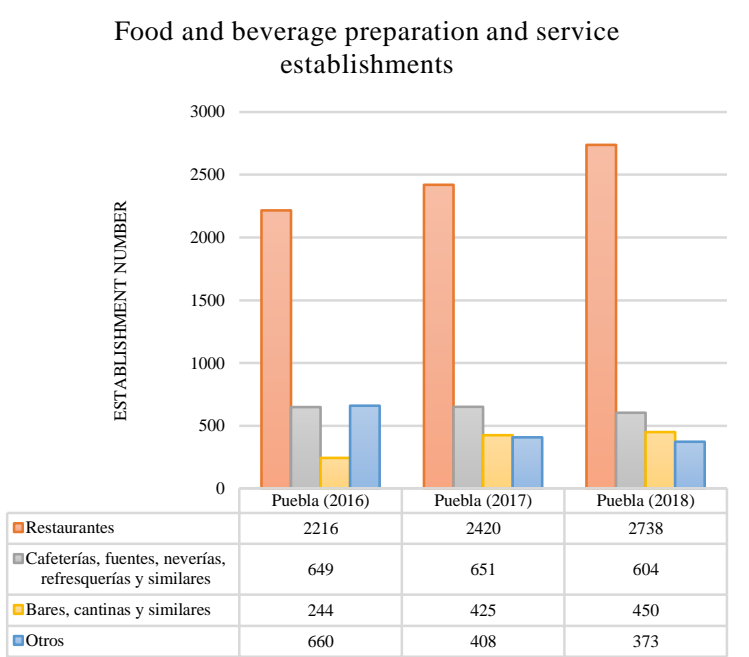

Figure 1 Food and beverage preparation and service establishments

Source: Based on the Statistical and Geographic Yearbook by State, 2016, 2017 and 2018

Note: Others (includes the Services of preparation of other foods for immediate consumption and night clubs, discotheques and similar).

The participation of the State of Puebla in the food and beverage establishment category for the year 2016 was 3,769 economic units headed by restaurants; and cafeterias, fountains, ice-cream parlours, soft drinks and similar establishments with 649, representing $58.79 \%$ and $17.2 \%$ respectively. For the year 2017, a total of 3,779 EU was registered, while restaurants increased by $8.4 \%$ (204 EU) with respect to the previous year, remaining the establishment with the greatest participation in the branch. 
For the year 2018, the national scale suffered a decrease of $29.94 \%$ (163,385 EU) over the previous year, a phenomenon that was not manifested in the State of Puebla, this time with an increase of $6.29 \%$ (262 EU), restaurantsmaintained development with $11.61 \%$ (318 EU).

According to the Statistical and Geographical Yearbook of Puebla (2017) for the year 2016 a total of 3,769 EU's was registered in this area, concentrating the municipality of Puebla $76.38 \%$ with 2,879 economic units. Restaurants represent $60 \%$ (1,734 EU) and cafeterias, soda fountains, refrigerators, soft drinks and similar represent $17.29 \%$ (4 EU).

\section{Current status of tourism in Puebla}

The tourist offers of the city according to diverse social and economic actors manifests that it is stagnant, and little taken advantage of; likewise it is identified that a deficiency exists in the tourist promotion and problems with the quality of the service provided. It is also indicated that the tourist offer requires more diversified products taking into account and excelling the gastronomic tourism, likewise the adaptation of schedules for the tourist attractions according to the needs of the tourists, training of the personnel that attends to the clients and improvements in the support infrastructure.

The tourist image of Puebla in Mexico is defined as a colonial city rich in religious architecture, and with a historic centre of great importance. Another characteristic element identified as positive within the image in Mexico, is its cuisine, highlighted by its emblematic dishes, it also mentions the fact that Mexicans, especially the inhabitants of Mexico City (CDMX) and the area around it, consider Puebla as a city of passage where you only go to eat and visit one or two places because the city of Puebla is World Heritage, this being another element that is necessary to consolidate and generate a broader awareness.

With regard to the image of Puebla abroad, it is believed that the idea is good, the city has colonial architecture and abundant religious art, mainly alludes to the American Baroque and excellent cuisine and various cultural traditions.
The difficulties that currently exist to commercialize and promote the city for tourism are the absence of a strategic promotion plan, and the lack of financial resources necessary to position the city as a tourist reference, taking into account elements such as: lack of institutional support, poor connectivity, lack of identity, CDMX wholesalers who must change tourist routes, communication and integration of tour operators and an adequate commitment of all sectors involved in tourism. Also, another problem is the low quality of the services offered, lack of professional knowledge of those responsible for tourism activity, so there is no integration of a saleable and properly consolidated tourism product.

The main opportunities for the development of tourism in the city stand out as its historical and cultural richness, the proximity to Mexico City and its gastronomy, followed by its geographical position, security and being a World Heritage Site.

\begin{tabular}{|l|l|}
\multicolumn{1}{|c|}{ Opportunities } & \multicolumn{1}{c|}{ Threats } \\
\hline Cultural Wealth & Growing insecurity \\
\hline $\begin{array}{l}\text { Proximity to Mexico } \\
\text { City }\end{array}$ & Other heritage cities \\
\hline Gastronomy & Garbage \\
\hline Geographical position & Lack of tourist awareness \\
\hline Security & $\begin{array}{l}\text { Problems connecting to Mexico } \\
\text { City }\end{array}$ \\
\hline Heritage City & Lack of promotion \\
\hline Weather & Mentality closed to change \\
\hline Universities & Neglect of heritage \\
\hline Crafts & Demotivation \\
\hline Colonial Art & Lack of connectivity \\
\hline Nature & Lack of information \\
\hline
\end{tabular}

Table 1 Opportunities and Threats of the environment that affect tourism in Puebla

Source: Strategic Tourism Plan of the City of Puebla, 2013

The participants from the different sectors interviewed agree that what the city lacks from the point of view of tourism is better signage, greater promotion and a strategic plan that allows it to disseminate the attractions and the tourist offer; therefore, it is necessary to have a comprehensive planning process with a sustainable sense and a more competitive vision that allows for a significant change in the mindset and image of the tourists who visit the city. 
In this way and taking into account that gastronomy represents an important symbol from the cultural and tourist point of view for the city as well as at a regional and national level, it is of vital importance to have a strategic plan on this culinary fact, which will allow the restaurant sector of the city of Puebla to be detonated. Also, detonate the sector of food providers such as small traders, small artisans, small farmers and also seek greater promotion of traditional markets that the city has.

The city of Puebla within this immense culinary wealth has a gastronomic calendar, which is the product of all the mergers that have taken place throughout its history and that give a symbolism and identity to the various sectors, mainly to the traditional cooks, this calendar responds to the agricultural cycles and also to the food elements that are given as the calendar year passes, so generate a strategic promotion of the cuisine would be a trigger for tourism in the city of Puebla.

\section{Proposal for a Tourism Competitiveness Strategy for the city of Puebla}

\section{Gastronomy Promotion Policy}

Derived from the Policy for the Promotion of National Gastronomy (2015), it is considered to create a Strategy of Tourist Competitiveness for the city of Puebla, which will allow the detonation of Puebla's gastronomy as a first order element, where the different secretaries of state that converge in the food system should be involved, as well as the civil associations of restaurateurs and service providers, it is also important to have the institutions of higher education that teach gastronomic studies and rural associations of food producers.

The main objective of this strategy is: to imply the conformation of the productive value chain of the gastronomy that requires the involvement and participation of the public, social and private sectors, and that entails from the small producer to the presentation and offer of the product to the final consumer.

In its elaboration process, the product is acquiring elements of quality, value, identity and roots that are providing its own characteristics that distinguish it from any other product, promoting its demand and preference.
In this sense, gastronomy is not only part of our economic policy but also of our cultural policy, since it is an invaluable heritage that requires an adequate promotion and diffusion of our gastronomic resources, especially the local and regional ones, since it provides a functional and social value for the town, since it is constituted as values, symbols and cultural richness. (Secretaría de Gobernacion, 2015)

\section{Cartography of food and beverage establishments}

In coordination with the civil associations of restaurateurs and hoteliers, it is recommended that a detailed inventory be made of the food and beverage establishments in the city's main tourist sites, whether within the old town or in other important commercial areas, which, due to their economic location, have food establishments; In this cartography it is tried to give to know the typologies of food that are sold, the classification of the establishments, the zones of location, taking into account if they are restaurants of homemade food, restaurants of poblano specialties or typical, gastronomic restaurants and restaurants in hotels; this way a guide could be generated elaborated with the main plates and specialties of each establishment, in order to be able to achieve a gastronomical route by which we can incursion with the tourists.

\section{Traditional markets}

One of the trends and tastes of tourism today is the appreciation of history, nature and the arts, which is linked to the enjoyment of good food and traditional drinks, prepared, based on local products, crafts and reproduced according to recipes inherited from ancestors. This trend is a model of life of an intellectual and philosophical position that has no geographical limits and that only a powerful incentive helped by tourism can achieve based on the creation and dissemination of gastronomic itineraries. In this way we can find that our traditional markets that at one time were places of supply for the local populations, have now become true captors of tourists who seek to find in them the delights and culinary traditions of the localities. The kitchens found in these establishments are mostly served by the socalled traditional cooks, who, faithful to their oral knowledge, execute daily the ancestral recipes, learned in the bosom of the family and that mostly obey gastronomic calendars according to the production of seasonal food. 
Today's gastronomic markets seek continuous fluidity, constantly presenting "new" products, new dishes and unusual and original techniques, just to mark a supposed status in the diner, the trends are shown as the future and new ways of preparing dishes. (Perea Balbuena, Carrasco Romero, \& Zamora Fernandez, 2019)

In this way, we intend to carry out different actions that will allow us to position these traditional places as a traditional tourist space by making an inventory of the current situation of these markets, as well as the foods that are sold in them, generating competitive actions that will allow us to combine the values and quality of the foods that are sold in them, taking into account that they should be clean and functional places so that they can create a function and exhibition for the sale of their products.

Also, plan the design and management of markets according to the seasonal food. Also, to offer constant tourist training courses in order to generate a culture of hygiene and food handling to be able to give a food security to our visitors.

\section{Gastronomic Calendar}

One of the main strategies that should consolidate the city of Puebla is to achieve a position as a culinary centre of Mexico, for which it is necessary to revalue the entire food system that occurs throughout a calendar year, so it suggests the promotion and creation of a system of time division, This exercise will allow us to promote the traditional dishes of Puebla's culture throughout the year and as we have pointed out, they are given due to the cultural and religious agricultural conditions.

In this way, in the months of February, March and April that coincide with the festivities of Lent and the main week, we have Lenten dishes and in the months of May that coincide with the first rains, we can taste maguey worms. In the months of June and August we will be able to taste foods with huitlacoches and mushrooms; also, the main fruits will be given like origin to the traditional dish of the Chile in walnut.
In the months of October-November we have the famous mole de caderas or huaxmole, in the month of November coinciding with the festivities of the Day of the Dead we also have traditional dishes that are put in the offerings and in the month of December in the Christmas festivities we are going to have traditional dishes of these seasons like the romeritos with shrimp, cod, tamales, chipotles stuffed with cheese, baked pork leg, shrimp pancakes in mole poblano, among others.

\section{Gastronomic Festivals}

As a complement to the gastronomic calendar is also proposed as a strategy to promote the cuisine of Puebla the realization of food festivals, the H. City Council of the municipality of Puebla declared from 2019 on May 17 as the "Day of the Cook and the Traditional Cook of the municipality of Puebla," so on this day you can make a festival of traditional cuisine, taking into account all the markets of the city of Puebla where you can display the dishes of the cuisine of Puebla. Another important festival would be the festival of mole poblano which is considered the baroque dish par excellence, which was created in the eighteenth century by the nuns of the convent of Santa Rosa, in this festival may participate both restaurateurs and housewives who continue to make this representative dish.

On the other hand, an important celebration would be the festival of chiles in walnut sauce that covers the months of July, August and September. This festival, which in some way has been traditional among restaurateurs, can be deepened to generate a more focused promotion of Mexico City's tourist market.

These events will allow us to bring regional tourists from neighbouring entities to the city of Puebla and thus raise the competitiveness of small and medium enterprises that are the restaurants that sell these typical dishes.

\section{Conclusions}

Business models must necessarily be accompanied by strategies for their execution. Arnoldo Hax, raises three basic considerations in the development of a strategy (Hax, 2001): 
a. The creation of economic value is the essential purpose of the strategy.

b. The creation of a unique value proposal for the client.

c. The generation of a sense of success.

The competitiveness of the organization lies in how it responds to the needs and expectations of customers, not only during the provision of service, although this may be the most important phase, but throughout the cycle of relationship with them. Identifying the needs and expectations of the customer allows the orientation of the strategies and resources of the establishment towards those processes that generate value in the perception of the customers.

A tourist market is basically composed of a tourist offer, this one is confirmed by the resources of the local economy, the tourist resources and the tourist products; For a tourist offer to have a participation in a competitive tourist market it must consider in the majority offer of the resources of the local economy an important attractiveness, an important participation in the tourist market, this consolidates the competitiveness within the offer of the tourist resources, finding this way a consolidated activity and an abundant participation in the tourist market; taking into account the offer of the tourist products we will be able to become competitive having an assured activity and a leading participation in the tourist market.

In order to achieve these objectives, it is necessary to have a quality of the tourist inputs, this quality will be reflected in an integral way and not fragmented with the sum of individual efforts, agreed by the companies, the locality and the municipality, which give sense to the quality of the destination. This quality must contain as universal references the globalization and the quality of standards, for it we need formation, training and conditions of work of the human resources, the use of the resources and sustainable processes, chains of responsible suppliers, better physical conditions of the facilities and the equipment's to the norms indicated by the competent legislations, as well as an ethical behaviour in the labour force; this way it will allow us to obtain certified seals and distinctive of quality in the establishments.
Mexican gastronomy is the third worldwide due to its variety where its multiple colours and flavours stand out, due to the use of diverse ingredients which when combined create a magic in the palate. As a result, UNESCO gave the category of Intangible Heritage of Humanity to Mexican Gastronomy in 2010. As part of this important Intangible and Cultural Heritage, Puebla's cuisine is presented, which has its own spirit and has been integrated by the norms that have characterized it, originating a geographic area determined by its land, waters, sky and inhabitants.

This kitchen poblana was born in their own spaces, also of origin to create their own utensils, produced their own inputs and invented their ways and ways of cooking, so that gave rise to have a repertoire of dishes that covers the full range of flavours spicy, sweet, sour, salty and what have given fame to the culinary poblana. This cuisine has also created its own schedules, customs and labels, so it has also been declared by state authorities as Intangible Heritage of the State of Puebla.

That is why it is important to theme a tourism product with the brand of Puebla's cuisine, and for this we need to use a series of strategic tools that allow us to make known more widely this cultural heritage, which represents us as a people, as a society, as a community and also gives rise to a number of small establishments. Hence, there are economic units through which diverse families subsist, which in turn also provide employment to artisans, producers, food introducers, etc.

In this way, having an adequate strategy will allow us to promote traditional gastronomy to a strategic market sector, it will also allow us to promote actions oriented to the development of tourist activities, which will allow us to generate income and jobs in the gastronomic sector, through services and events, at the same time, it will help us to generate normative instruments that transform and preserve Puebla's gastronomy by granting incentives, certificates and recognitions to gastronomic entrepreneurs. Similarly, it will help us to strengthen the infrastructure of traditional markets, ensuring their quality and experience, with this we will be able to achieve a better quality of life in the actors who have to do with the creation and promotion of gastronomy in Puebla. 
For this reason, in Puebla the gastronomy of Puebla is not only a food, but a way of life, it is a way of behaving and it is a way of expressing ourselves as a people and a community.

\section{References}

Carrasco Romero, V. J. (2015). Evaluar en Nivel de Competitividad de las Pymes que cuentan con Certificación Tesoros de México, caso: Centro Histórico de la ciudad de Puebla. Puebla: BUAP.

Dirección de Turismo Municipal, H. Ayuntamiento del Municipio de Puebla. (2015). Plan Estratégico de Turismo (PLANDETUR). Puebla: H. Ayuntamiento del Municipio de Puebla.

Giménez, Gilberto. (2005). Teoría y análisis de la cultura. Editorial CONACULTA, México, D.F.

Hax, A. (diciembre de 2001). The Delta Model--Discovering New Sources of Profitability in a Networked Economy. European Management Journal,Vo. 19, No. 4 , 379---391.

INEGI. (2017). Anuario Estadístico y Geográfico de Puebla 2017. México: Instituto Nacional de Estadística y Geografía.

INEGI. (2018). Anuario Estadístico y Geográfico por entidad federativa 2018. México: Instituto Nacional de Estadística y Geografía.

INEGI. (2019). Anuario Estadístico y Geográfico por entidad federativa 2019. México: Instituto Nacional de Estadística y Geografía (INEGI).

Kaplan, A., \& Carrasco, S. (1999). Migración, cultura y alimentación. Barcelona: Universidad de Barcelona.

López P., R. O. (2009). Competitividad Turística. Política y Administración, 131---147.

Lundbergg, D. (2012). Organización y Administración de Hoteles y Restaurantes. Centiun.

Magaña, Orestes. (2012). Historia de la Gastronomía de la Ciudad de Puebla. Editorial Ediciones Puebla. Puebla, México
Medina, X. (2002). Alimentación etnicidad y migración. En M. García, Somos lo que comemos (pág. 124). Barcelona: Ariel.

Millán, A. (1991). Identidad cultural e innovación alimenticia. Londres: Universidad de Nantes.

Osterwalder, A. (diciembre de 2014). How to Describe and Improve your Business Model to Compete Better. Obtenido de www.arvetica.com

Perea Balbuena, J., Carrasco Romero, V., \& Zamora Fernández, M. (2019). Certification proposal for the traditional professional cook of the state of Puebla. Journal-Labor and Demographic economics, 14-24.

Sánchez Hernández, A. A. (2008). Efectos de las Delimitaciones del Centro Histórico de Puebla. En A. Álvarez Mora, \& F. Valverde Díaz de León, Ciudad, Territorio y Patrimonio, Materiales de Investigación III (pág. 78). Puebla: Lupus Inquisitor.

Secretaría de Gobernación. (2015). Diario Oficial de la Federación. Obtenido de ACUERDO para instrumentar la Política de Fomento a la Gastronomía Nacional.: http://dof.gob.mx/nota_detalle.php?codigo=540 5996\&fecha $=02 / 09 / 2015$

Vergara, S. (2009). Historia e importancia en el transcenso de la vida de la Puebla de los Ángeles. Puebla: INAH.

Weber, k., \& Chon, K. S. (2002). Convention Tourism: International Research and Industry Perspectives. OMT.

World Economic Forum (WEF). (diciembre de 2014). Indice de competitividad en viajes y turismo. Obtenido de http://www.weforum.org/reports/ 